Sains Malaysiana 50(9)(2021): 2713-2725

http://doi.org/10.17576/jsm-2021-5009-18

\title{
Biomechanical Analysis of an Improvement of Prosthetic Liner using Polyurethane Focusing at the Anterior-Distal Part of Residual Limb: A Case Study
}

(Analisis Biomekanik Pelapik Prostetik yang telah Ditambahbaik menggunakan Poliuretana Memfokus pada Bahagian Hujung Bawah Anggota: Suatu Kajian Kes)

Mohamed Afifuddeen bin Mohamed Nizam, Nasrul Anuar Abd RazaK* \& Noor Azuan Abu Osman

ABSTRACT

Most transtibial prosthesis users always experience pain sensation at the distal of the residual limb due to bony prominences and nerve endings. Many initiatives have been taken to resolve this problem, including using softer materials such as silicone or gel liner and designing a distal off load prosthetic socket. Another promising approach is to incorporate polyurethane foam in the manufacturing of prosthetic liner. This study aimed to design a new prosthetic liner using polyurethane at the anterior-distal part of the residual limb as a Pelite replacement and to compare the biomechanical gait analysis between the new modified polyurethane liner and the common Pelite liner. A unilateral transtibial amputee was recruited as the subject. Two Patellar Tendon Bearing transtibial prostheses with different liners were fabricated for the subject, which were Pelite liner and a modified polyurethane foam liner. The modified liner using polyurethane foam consisted of Ethylene vinyl-acetate - Polyurethane - Ethylene vinyl-acetate sandwich placed at the anterior-distal part of the residual limb. The Ethylene vinyl-acetate - Polyurethane - Ethylene vinyl-acetate sandwich function was to improve the walking gait and compensate for the pain sensation experienced by the subject when wearing the Pelite liner. Biomechanical analysis was done using the Vicon Motion Analysis System on the subject when using the two newly fabricated transtibial prostheses and the subject's original prosthesis with Pelite liner. During the loading response phase, the original liner exerted a slightly higher force than the Pelite and the modified liner. At 30\% and 50\% of the gait cycle, the original liner exerted low force than the Pelite liner and the modified liner for Ground Reaction Force at the amputated side. However, no significant difference $(p>0.05)$ was found between all prosthetic liners for Ground Reaction Force (Non-Amputated). The biomechanical analysis showed that the modified liner using polyurethane foam improved the prosthesis user gait cycle and the walking gait of the prosthesis user.

Keywords: Gait analysis; polyurethane; rehabilitation; transtibial liner

ABSTRAK

Kebanyakan pengguna kaki palsu bawah lutut sering mengalami kesakitan pada bahagian hujung anggota disebabkan oleh penonjolan bertulang dan ujung saraf. Telah banyak inisiatifyang telah dilakukan untuk menyelesaikan masalah ini, termasuklah menggunakan bahan lembut seperti pelapik silikon atau pelapik gel dan mereka bentuk soket prostetik tiada beban di bahagian hujung anggota. Antara pendekatan lain ialah menggabungkan busa poliuretana di dalam pembuatan pelapik prostetik. Kajian ini bertujuan untuk mereka bentuk pelapik prostetik baharu menggunakan poliuretana pada bahagian hujung bawah anggota sebagai pengganti Pelite dan membandingkan analisis gait biomekanik di antara pelapik poliuretana yang diubah suai dan pelapik Pelite biasa. Seorang amputee bawah lutut telah direkrut sebagai subjek. Dua kaki palsu bawah lutut Tendon Patellar dengan dua pelapik yang berbeza telah dibuat untuk subjek, iaitu pelapik Pelite dan pelapik poliuretana yang diubah suai. Pelapik poliuretana diubah suai terdiri daripada gabungan Etilena vinil asetat - Poliuretana - Etilena vinil asetat yang diletakkan pada hujung bawah anggota. Fungsi gabungan Etilena vinil asetat - Poliuretana - Etilena vinil asetat ialah untuk memperbaiki langkah gait dan mengimbangi sensasi kesakitan yang dialami oleh subjek semasa memakai pelapik Pelite. Analisa biomekanik 
telah dilakukan menggunakan Sistem Analisa Gerakan Vicon ke atas subjek ketika menggunakan kedua-dua kaki palsu baharu dan kaki palsu asal dengan pelapik Pelite miliknya. Semasa fasa tindak balas, pelapik asal miliknya menghasilkan daya yang agak tinggi berbanding pelapik Pelite berbanding pelapik yang diubah suai. Pada $30 \%$ dan $50 \%$ kitaran gait, pelapik asal miliknya menghasilkan daya yang kurang berbanding pelapik Pelite dan pelapik yang di ubah suai untuk Daya Tindak Balas Tanah di bahagian sebelah badan yang diamputasi. Namun begitu, tiada perbezaan ketara $(p>0.05)$ yang telah ditemui antara kesemua pelapik prostetik untuk Daya Tindak Balas Tanah (Tidak Diamputasi). Analisa biomekanik menunjukkan bahawa pelapik yang diubah suai menggunakan poliuretana memperbaiki kitaran gait dan langkah gait bagi pengguna kaki palsu.

Kata kunci: Analisa gait; pelapik bawah lutut; poliuretana; rehabilitasi

\section{INTRODUCTION}

Limb loss or known as limb amputation is becoming more common nowadays. Amputation can be performed at any level of the limb, but lower limb amputation is the most common cases (Anderson et al. 2007; Kirkup 2007; Miller et al. 2017). A person is amputated because of vascular disease, trauma, and the growth of tumour or infection from previous injuries or diseases. A person can also have congenital limb loss or limb deficiency at birth (Biddiss \& Andrysek 2011; Smith 2004). In medical practices, limb amputation is the last option for the surgeon to save the remaining limbs from any further damage.

One of the most popular major limb amputations in Malaysia is lower limb amputation. There are many types of lower limb amputations such as hip disarticulation, transfemoral amputation, knee disarticulation, and transtibial amputation. The most common type of lower limb amputation is transtibial amputation (43.5\%), followed by partial foot amputation $(36.3 \%)$ and transfemoral amputation (16.2\%) (Nazri et al. 2015).

After amputation, a person cannot ambulate as a normal person without an assistive device or prosthesis. A prosthetic device is defined as any device that replaces a missing body part. The prosthetic socket is the most important part that acts as an interface medium between the prosthesis and the residual limb. The socket design must be perfectly catered to the user's needs to achieve satisfactory load transmission, efficient ambulatory control, and stability. The knee range of motion also needs to be considered when designing a prosthetic socket (Van Valkenburg et al. 2016). There are two different essential ideologies for designing a transtibial socket. The first one is consistently distributing the weight of the body over the residual limb. Another one is distributing most of the weight over precise weightbearing regions at the residual limb (Ali et al. 2015; Sadeeq 2015).

There are two common socket designs used in fabricating transtibial prosthesis, which are patellartendon-bearing (PTB) socket and total surface bearing (TSB) socket. The prescription of type of the socket is decided based on the user needs and pathology (McMonagle et al. 2007).

As the name suggests, the patellar-tendon-bearing (PTB) socket concentrated the load-bearing on the patellar tendon (Figure 1). Meanwhile, the rest of the residual limb has less load-bearing onto it. The PTB socket is suitable for patients with a medium to long stump and no knee contracture. Furthermore, this particular design is suitable for users who experienced pain at the distal part of the residual limb. It is because the weight of the user is concentrated at the patellar tendon area rather than the distal part of the residual limb.

In addition, there are also sub designs for PTB socket, which are patellar-tendon-bearing-supracondylar (PTB$\mathrm{SC}$ ) socket and patellar-tendon-bearing-supracondylarsuprapatellar (PTB-SC-SP) socket. The trim line of PTB-SC socket rises above supracondylar which acts as an anatomical suspension for the user. This socket is designed for patients with long to short stump length, peripheral vascular disease, and mild mediolateral knee ligament laxity (McMonagle et al. 2007). As for PTBSC-SP socket, the trim line rises above supracondylar and encapsulates the patellar, which also acts as an anatomical suspension for the user. This socket design 
is usually prescribed for patients with a medium to very short stump length, moderate mediolateral knee ligament laxity, mild anteroposterior knee ligament laxity, and peripheral vascular disease. However, the disadvantage of this design is the user has a limitation when flexing the knee (McMonagle et al. 2007).

However, protecting the remaining soft tissues at the residual limb of lower limb amputees remain a tough challenge. Residual limb soft tissues are not designed to bearing weight, unlike the foot plantar tissues (Dudek et al. 2005). Repetitive load on the soft tissues of the residual limb by the prosthetic socket can cause ulceration and other skin condition (Sankaran et al. 2019). The pain experienced at the distal part of the residual limb is mainly caused by the high stress or pressure on it (Ghoseiri et al. 2018; Lee et al. 2005). A missfit socket can cause pistoning during walking, leading to excessive stress and friction on the residual limb (Klaassen et al. 2019). On the other hand, the prosthetist also prescribed softer materials for the prosthetic liner to combat this problem. Liner acts as an interface between the residual limb and the prosthetic socket, is to provide cushioning to the residual limb (Andrysek \& Eshraghi 2016; Eshraghi et al. 2015).

Pelite foam is a top choice material to use as a prosthetic liner around the world. Pelite foam is a closedcell polyethylene foam and manufactured in various hardness and thickness. Pelite foam is a high temperature thermoplastic and can be easily formed over positive model after heating. Pelite liner as in Figure 2 often prescribed for patients with peripheral disease, sharp bony prominences on the stump and thin sensitive skin. The advantages of Pelite liner include acting as weightbearing because of the softness and allowing volume fluctuation of the stump.
Another common choice of material for prosthetic liner is silicone. The properties of silicone liner include soft, sticky, and closely followed the contours of the residual limb making it really suitable for users that have skin problems. All of the properties stated can prevent abrasion of the skin due to minimal friction between the skin and the liner. Abrasion and friction onto the skin can cause injury and lead to discomfort and pain to the user in a long time (Li et al. 2011).

Gait analysis is an important indicator in deciding the walking pattern and stability in the motion of an individual. A usual gait analysis comprises of two parts, the stance, and the swing phase. The stance phase includes the initial contact or heel strike where the heel touches the ground. Then, the loading response or foot flat to prepare the body before accepting the body mass or weight on a single limb. When moving forward to the midstance, the weight of the body is completely balanced on a single limb. Terminal stance or heel off is the last part of the stance phase. The swing phase includes the pre-swing, initial swing, mid-swing and terminal swing. A lower limb amputee must have a gait cycle close to a normal person to ambulate without having to compensate at other joints or limbs. The gait cycle phase is shown more clearly in Figure 3.

There were two main objectives of this research. The first objective was to design a new prosthetic liner using polyurethane at the anterior-distal part of the residual limb as a replacement for Pelite as a prosthetic liner. The other objective was to compare the biomechanical gait analysis of the new modified liner using polyurethane with the common Pelite as liner.

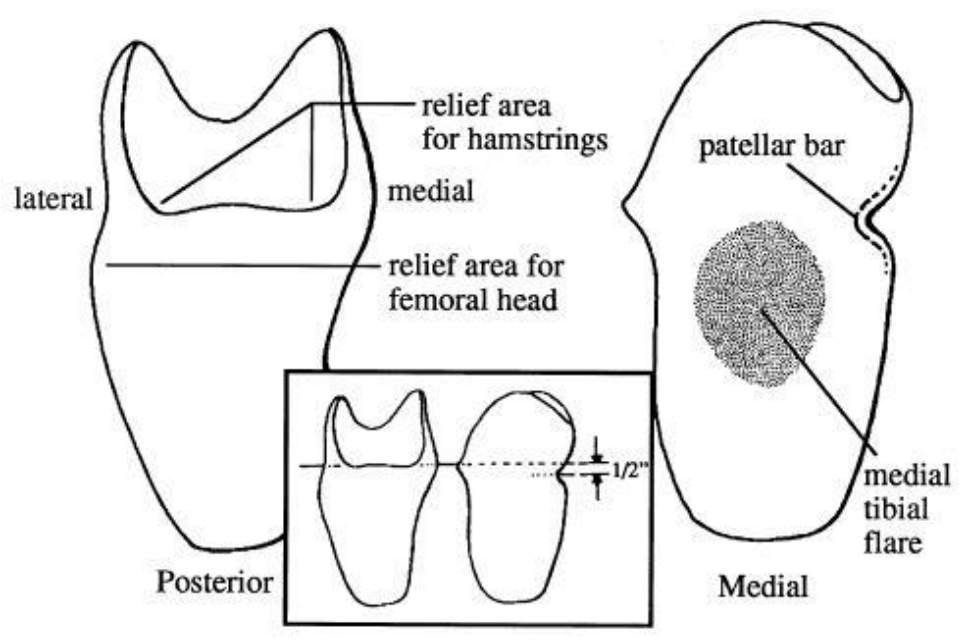

FIGURE 1. Transtibial socket 


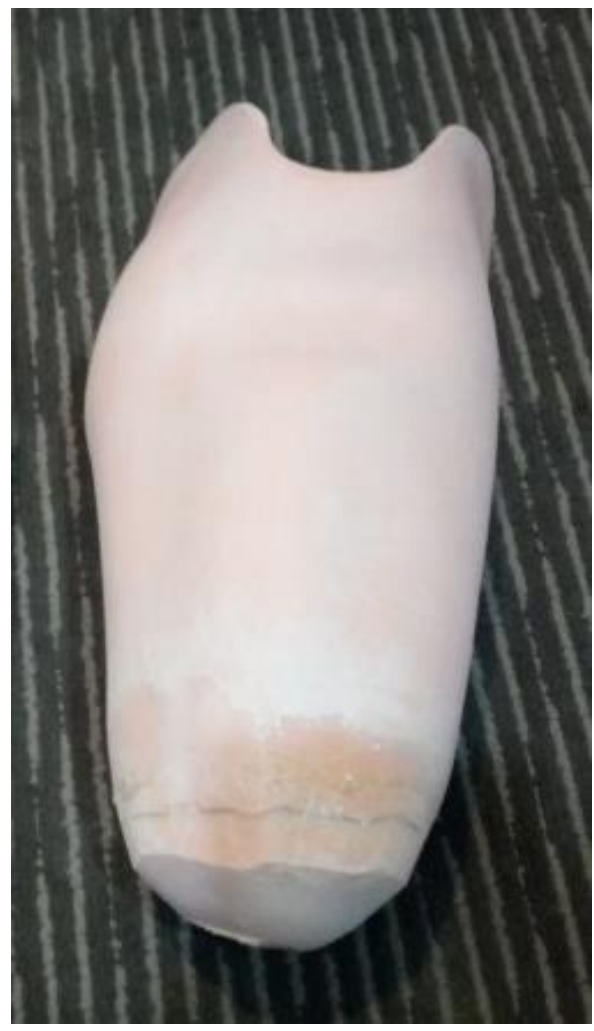

FIGURE 2. Pelite liner

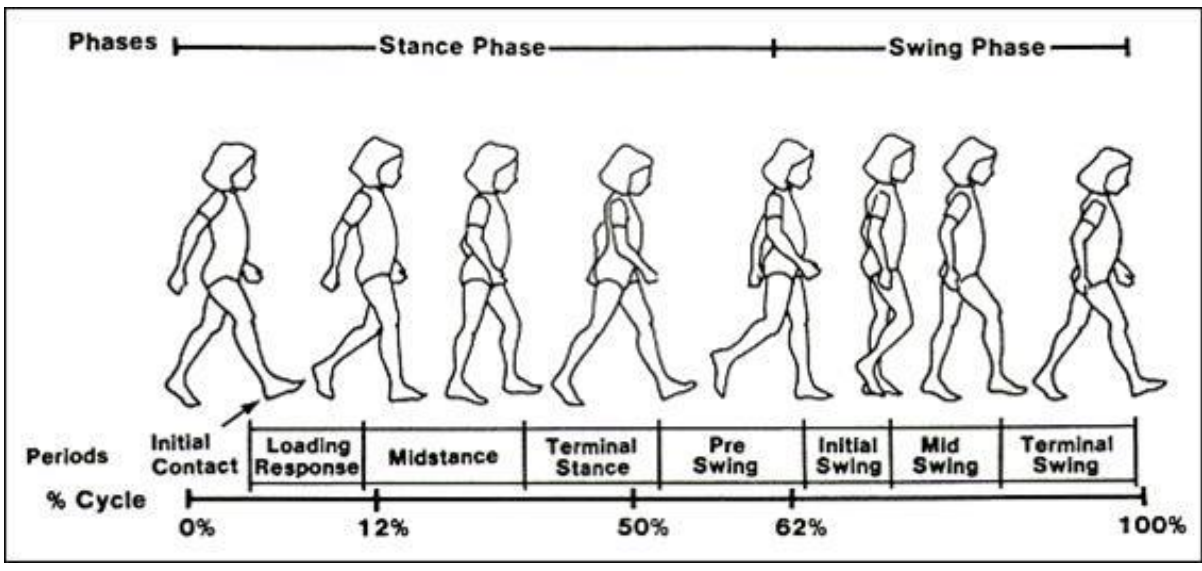

FIGURE 3. Gait cycle phase 


\section{MATERIALS AND METHODS}

\section{ETHICS APPROVAL AND CONSENT}

This research was approved by the National Medical Research Register Secretariat 37912 and conducted under the guidance of Certified Prosthetist and Orthotist (CPO) of International Society of Prosthetics and Orthotics (ISPO) Category2.

\section{SUBJECT RECRUITMENT}

One subject with unilateral transtibial amputee was recruited in this study. Informed written approval was obtained from the subject. The subject was an experienced prosthetic user (more than 6 months). Table 1 shows the objective assessment of the subject. The inclusion criteria of the subject included: minimum 15 $\mathrm{cm}$ residual limb, no serious skin condition (i.e. no visible wound and ulcers in the residual limb), no drastic volume changes, and able to walk without the use of assistive devices.

TABLE 1. Objective assessment of the subject

\begin{tabular}{ll}
\hline Sex & Male \\
\hline Age (years) & 25 \\
Amputation (years) & 8 \\
Amputation cause & Trauma \\
Height $(\mathrm{cm})$ & 162 \\
Weight $(\mathrm{kg})$ & 55 \\
Residual limb length $(\mathrm{cm})$ & 15.5 \\
Circumference $(\mathrm{cm})$ & 34 \\
Liner type & Pelite \\
Activity level & K-4 \\
\hline
\end{tabular}

\section{PROSTHETIC INTERVENTION}

Two transtibial prostheses were fabricated for the subject. They were made with the identical type of components using two different liners: Pelite liner and modified liner using polyurethane foam. Both prostheses were fabricated by the same prosthetist to avoid any alterations due to manufacturing, alignment, and fitting.

First, the subject's residual limb was wrapped with cling wrap. All landmarks and bony prominences were marked with indelible pencil and all measurements were recorded correctly. Plaster of Paris (POP) bandages were soaked in water and wrapped to the subject's residual limb. The POP bandages were massaged to capture the contour of the residual limb. The cast was removed from the residual limb once it was dried. All marks were refreshed using an indelible pencil and filled with POP slush. The negative cast was removed and recommended modification was done on the positive model. Then, Pelite liner was fabricated onto the positive model and 
polypropylene plastic was draped onto it. The procedure was repeated for the liner with modification. The anterior-distal of the liner was added with the EVApolyurethane-EVA sandwich as shown in Figure 4. The polyurethane and EVA sheets were first cut into cut-out as shown in Figure 5(A). Then, the cut-outs were assembled into a sandwich as in Figure 5(B) and glued together. Finally, the sandwich was placed at the anterodistal of the positive model as shown in Figure 5(C) before the Pelite draping process. All components were together to make 2 prostheses.

\section{BIOMECHANICAL ANALYSIS}

The biomechanical analysis was conducted using the Vicon Motion Analysis System (Vicon; United Kingdom), which has an accuracy level of less than $\pm 0.1 \mathrm{~mm}$. The system works by capturing the motion of the subject when doing numerous activities such as walking, running, and jumping. The usage of this system provided more reliable and accurate results (Gholizadeh et al. 2012). There were five MX T40-S cameras used to capture the video of the activities. Two force plates were embedded in the middle of the capture volume. Using the Kistler 9821C force plate technology (USA) with a frequency of $1000 \mathrm{~Hz}$. Force plates recorded ground reaction forces when the subject walked on it. However, for the moments and powers, the forces need to be calculated through inverse dynamic analyses. The subject was required to walk with both prostheses in the gait analysis laboratory under the supervision of the prosthetist. The system used for biomechanical analysis was Vicon Nexus 1.8.5 Motion Analysis System. First, the system was set up and the required calibrating process was done. The details of the subject such as the width of the left and right ankle, and the width of the left and right knee were measured using a body caliper. The length of the residual limb was measured using a measuring tape. All the measured parameters, the height and weight of the subject were recorded in the system software. The subject was attached with 16 reflectors on his lower limbs both left and right such as the anterior superior iliac spine, posterior superior iliac spine, thigh, calf, head of the tibia, second toe, heel and the lateral malleolus following the Helen Hayes marker set (Staros 1988). The subject was asked to walk at his preferred constant speed, which was monitored through the Vicon Motion Analysis System from one point to another with the requirement of both feet step on the force plates separately using three different liners: the Pelite liner, the modified liner and his original liner. The activity was repeated 13 times for each liner. The sampling rate chosen for the data collection was 100 $\mathrm{Hz}$. The signals from the motion analysis system were filtered by a Butterworth filter with the cut-off frequency of $10 \mathrm{~Hz}$. The gait analysis data were recorded and analysed using Microsoft Excel.

\section{RESULTS}

The prosthetic liner with polyurethane modification was produced as shown in Figure 4. Biomechanical gait analysis was performed on the subject to determine whether Pelite liner and modified liner using polyurethane foam affected the gait of the subject. Vicon Motion Analysis System was used in this study to perform the motion analysis experiment.

The results obtained from the gait analysis experiment were analysed into 8 different graphs as presented in Figure 6(A) - 6(H). The graphs that have generated were; ground reaction force for both left and right side of the body, right ankle angle, right ankle power, left knee angle, left knee power, right knee angle, and right knee power. For each graph, there were 3 different data plotted, the first one was the gait of the subject using Pelite liner, followed by the gait of subject using the modified liner and the gait of the user using his original liner.

Table 2 shows the average and standard deviation of parameters in gait analysis. The maximum knee flexion at the stance phase for all three liners for the amputated side were consistent; Pelite $\left(0.2^{\circ}\right)$, modified $\left(0.3^{\circ}\right)$, and original $\left(0.3^{\circ}\right)$. The non-amputated side also showed consistent knee flexion angle at the stance phase for all three liners; Pelite $\left(-4.7^{\circ}\right)$, modified $\left(-4.2^{\circ}\right)$, and original $\left(-5.0^{\circ}\right)$. Next, the maximum knee flexion during the swing phase for the amputated side were consistent for all three liners. For the non-amputated side, the original liner showed higher maximum knee flexion during the swing phase $\left(62.7^{\circ}\right)$ than the Pelite liner $\left(57.8^{\circ}\right)$ and modified liner $\left(57.9^{\circ}\right)$. Significant differences $(p<0.05)$ were identified at the $1^{\text {st }}$ peak of vertical ground reaction force between all three liners. The subject produced greater ground reaction force at first peak for both amputated and non-amputated sides than the other two liners. Meanwhile, at the $2^{\text {nd }}$ peak of vertical ground reaction force, the subject produced lesser ground reaction force than the other two liners. 


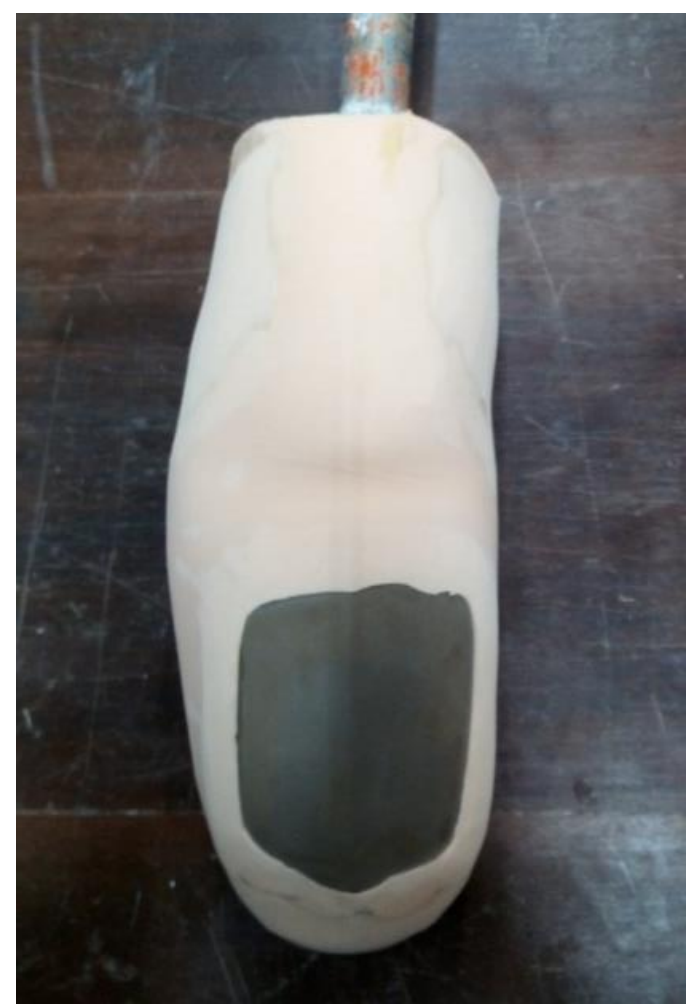

FIGURE 4. Prosthetic liner with polyurethane foam modification

TABLE 2. Average and standard deviation (in bracket) of parameters in gait analysis

\begin{tabular}{|c|c|c|c|c|c|c|}
\hline \multirow[t]{2}{*}{ Parameters } & \multicolumn{2}{|l|}{ Pelite } & \multicolumn{2}{|l|}{ Modified } & \multicolumn{2}{|l|}{ Original } \\
\hline & $\begin{array}{l}\text { Amputated } \\
\text { side }\end{array}$ & $\begin{array}{l}\text { Non-amputated } \\
\text { side }\end{array}$ & $\begin{array}{l}\text { Amputated } \\
\text { side }\end{array}$ & $\begin{array}{l}\text { Non-amputated } \\
\text { side }\end{array}$ & Amputated side & $\begin{array}{l}\text { Non-amputated } \\
\text { side }\end{array}$ \\
\hline $\begin{array}{l}\text { Knee position at } \\
\text { initial contact }\left(^{\circ}\right)\end{array}$ & $6.8(1.5)$ & $6.2(2.3)$ & $7.8(1.1)$ & $5.8(2.6)$ & $0.2(2.1)$ & $13.2(1.3)$ \\
\hline $\begin{array}{l}\text { Maximum knee } \\
\text { flexion at stance }\left(^{\circ}\right)\end{array}$ & $0.2(0.4)$ & $-4.7(2.0)$ & $0.3(1.7)$ & $-4.2(2.2)$ & $0.3(0.3)$ & $-5.0(3.0)$ \\
\hline $\begin{array}{l}\text { Maximum knee } \\
\text { flexion during } \\
\text { swing }\left(^{\circ}\right)\end{array}$ & $79.1(2.3)$ & $57.8(1.2)$ & 79.4 (1.6) & $57.9(1.6)$ & $80.1(1.3)$ & $62.7(1.6)$ \\
\hline $\begin{array}{l}\text { Vertical GRF, } 1^{\text {st }} \\
\text { peak }(\mathrm{N})\end{array}$ & $101.8(0.3)$ & $110.7(0.5)$ & $98.3(0.2)$ & $107.7(0.5)$ & $105.4(0.2)$ & $111.6(0.2)$ \\
\hline $\begin{array}{l}\text { Vertical GRF, } 2^{\text {nd }} \\
\text { peak }(\mathrm{N})\end{array}$ & $104.3(0.2)$ & $97.0(0.1)$ & $105.2(0.2)$ & $97.5(0.3)$ & $99.3(0.2)$ & $97.5(0.2)$ \\
\hline
\end{tabular}




\section{DISCUSSION}

Polyurethane foam is a softer material when comparing with Pelite foam. This study incorporated polyurethane foam in the manufacturing of prosthetic liner. The polyurethane foam was incorporated between two EVA foam to build a sandwich of EVA-polyurethane-EVA as shown in Figure 5(B). The sandwich was then placed at the anterior-distal part of the positive model as shown in Figure 5(C). The user often complained that they always experienced the pressure that caused pain at the anteriordistal part of the residual limb when wearing the Pelite liner. Therefore, the EVA-polyurethane-EVA sandwich was placed at the anterior-distal part of the residual limb to compensate for the pain sensation experienced by the user at the residual limb (Eshragi et al. 2015). Previously, silicone was used as the soft material to compensate for the pain sensation at the residual limb (Eshragi et al. 2015). Then, the Pelite foam was draped onto the positive model with EVA-polyurethane-EVA sandwich. The part of the sandwich on the Pelite liner was cut off and the edge was glued together.

Biomechanical gait analysis was performed on the subject to determine the effect of different prosthetic liners on the gait of the subject. The Vicon Motion Analysis System was used to perform the motion analysis experiment. Three different prosthetic liners were used: Pelite liner, modified liner using polyurethane foam, and original Pelite liner that has been used by the subject. There were 13 experimental trials performed for each type of liner. Then, the average was calculated from all of the trials after the data was analysed.

The ground reaction force is the equal and opposite force that acts on a body when the body exerted some force while resting or hitting the ground (Porter 2013). By analysing the ground reaction force, the force exerted by the body during the gait cycle can be studied. In this study, it showed that the subject walked better using the modified liner followed by the Pelite liner and walked worst in his original liner. Based on the Ground Reaction Force (Amputated) graph in Figure 6(A), no significant difference was found between all three types of liners during the gait cycle. At $20 \%$ percent of the gait cycle which was the loading response phase, the original liner exerted slightly higher force than Pelite and modified liner. Meanwhile, at $30 \%$ and $50 \%$, the original liner exerted a lower force than the Pelite liner and modified liner. This showed that the subject has inconsistent Ground Reaction Force while wearing his original liner. Based on the Ground Reaction Force (Non-Amputated) graph in Figure 6(B), no significant difference $(p>0.05)$ was observed between all prosthetic liners. This is because the prosthetic user is a left transtibial prosthesis. Thus, the force exerted by the left side of the body should be almost the same.

The subject used more ankle power (NonAmputated) when using his original liner because he has the highest angle throughout the phases, followed by the modified liner and Pelite liner. The greater angle values caused high power output from the subject (Plitz et al. 1993). The result showed that the original Pelite liner exerted slightly higher ankle power than Pelite and modified liner as shown in Figure 6(D). There are many potential reasons for this output, including the alignment of the prosthesis, mechanical characteristics of the feet, or others. A study by Esposito et al. (2017) stated that various external reasons that might affect the output of the gait analysis experiment. Even though the graph was based on the sound limb of the user, the prosthesis side might affect the gait of the sound side as the sound side need to compensate for the prosthesis side. This study did not analyse the left ankle because at the prosthesis side, the ankle angle was not reliable since the usage of SACH foot caused the ankle stiff. Only the prosthetic foot was flexible.

There was a major difference between the Knee Angle (Amputated) graph and Knee Angle (NonAmputated). This study showed that the Knee Angle (Amputated) has a greater angle value than the Knee Angle (Non-Amputated) for all three liners, which resulted in the weight of the prosthesis. The prosthesis was considered foreign to the body, so the subject needed to compensate for the weight of the prosthesis. Grimmer et al. (2017) found that the prosthesis user needed to compensate for the weight of the prosthetic limb when ambulating thus affected the user's gait. In the same scenario with the Knee Power, Knee Power (Amputated) was higher than Knee Power (Non-Amputated) throughout the gait phase. This result supported the early statement that the user needed to compensate for the weight of the prosthesis when walking. 
A

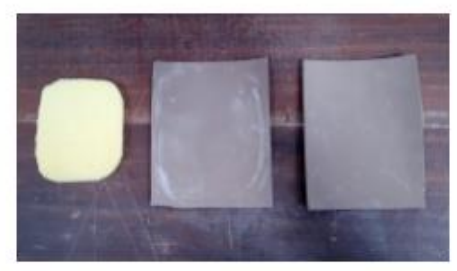

B

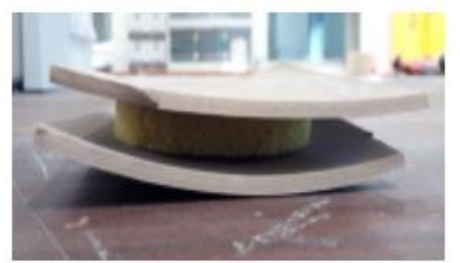

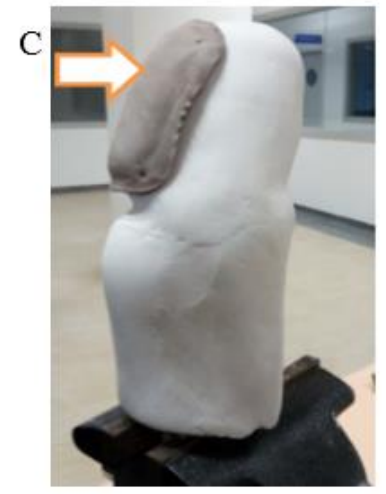

FIGURE 5. The steps of polyurethane modification onto the liner (A) The polyurethane and EVA cut-out; (B) The EVA-polyurethane-EVA sandwich; (C) The EVA-polyurethane-EVA sandwich placement onto the positive model

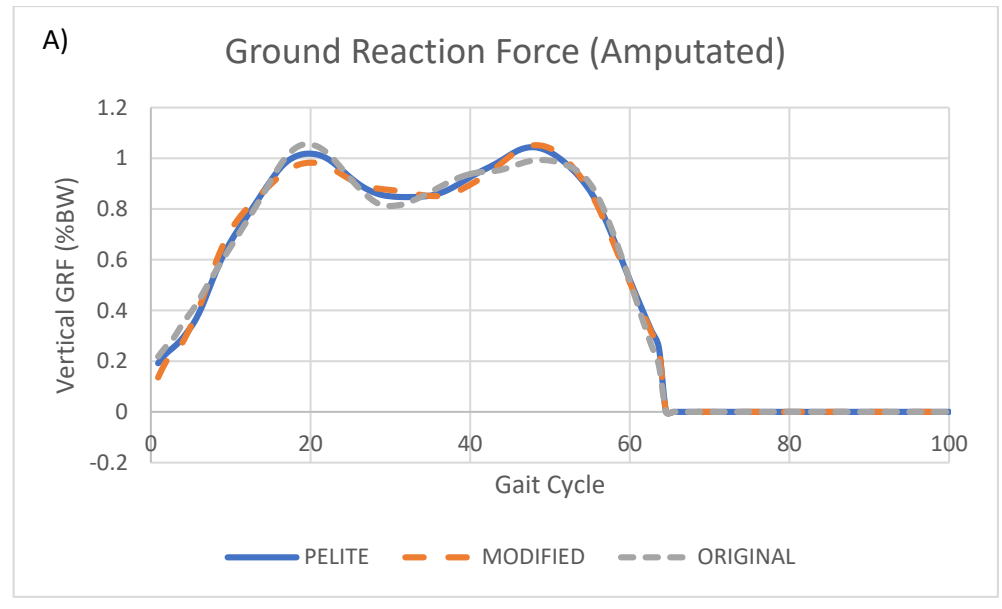

B)

Ground Reaction Force (Non-Amputated)

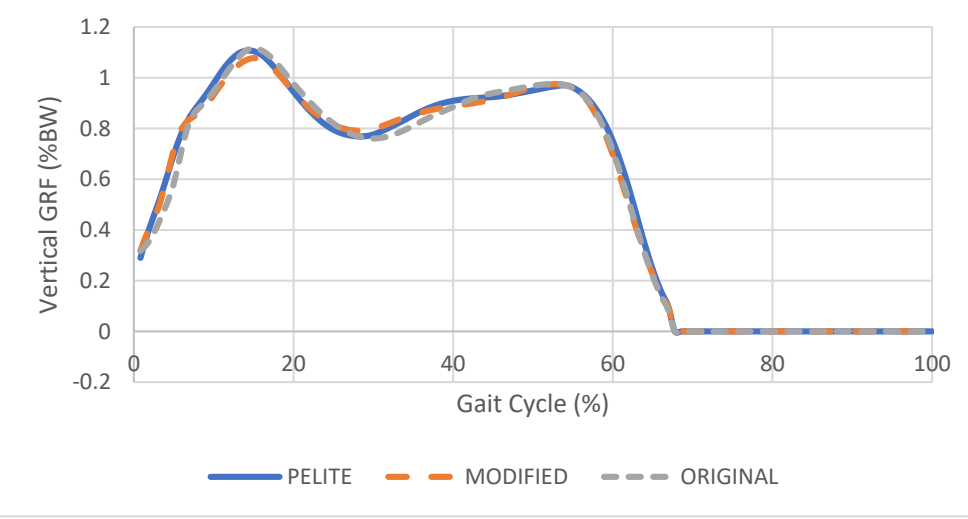




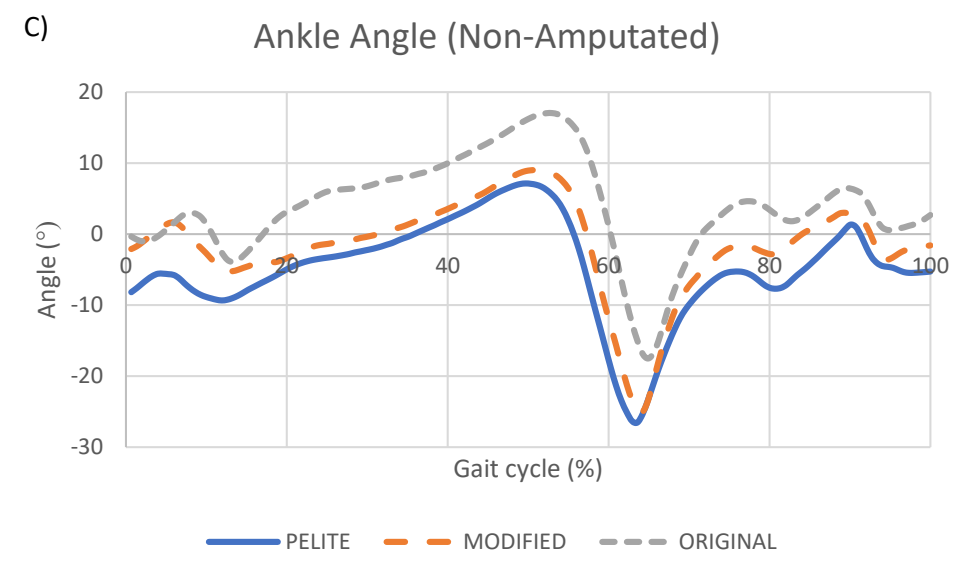

D) Ankle Power (Non-Amputated)

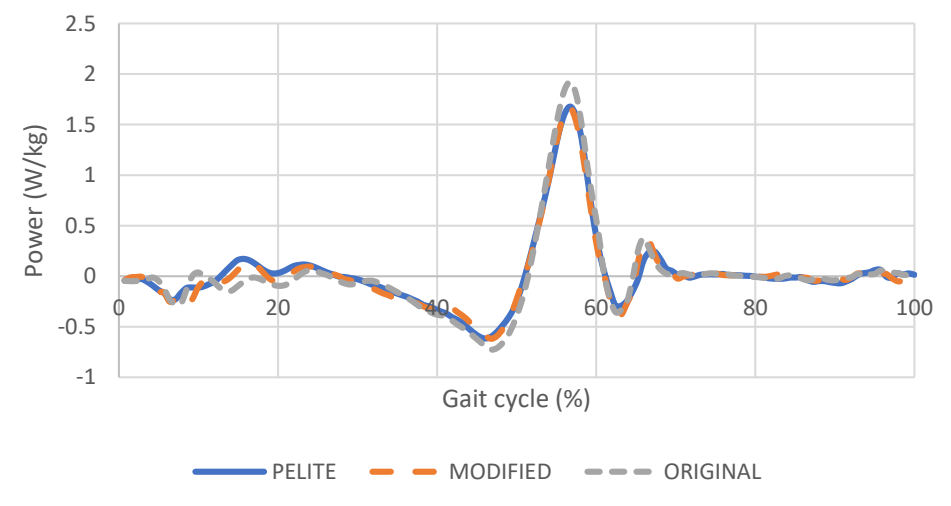

E) Knee Angle (Amputated)

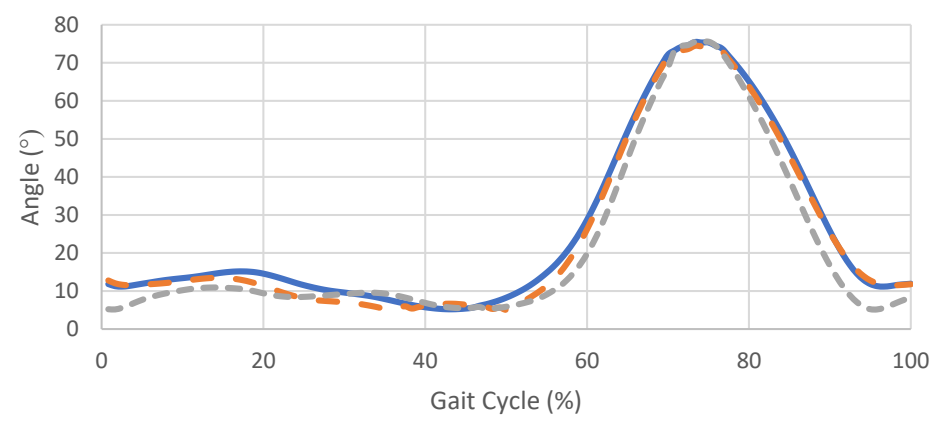

$\longrightarrow$ PELITE - MODIFIED $-\infty$ ORIGINAL 
F) Knee Power (Amputated)

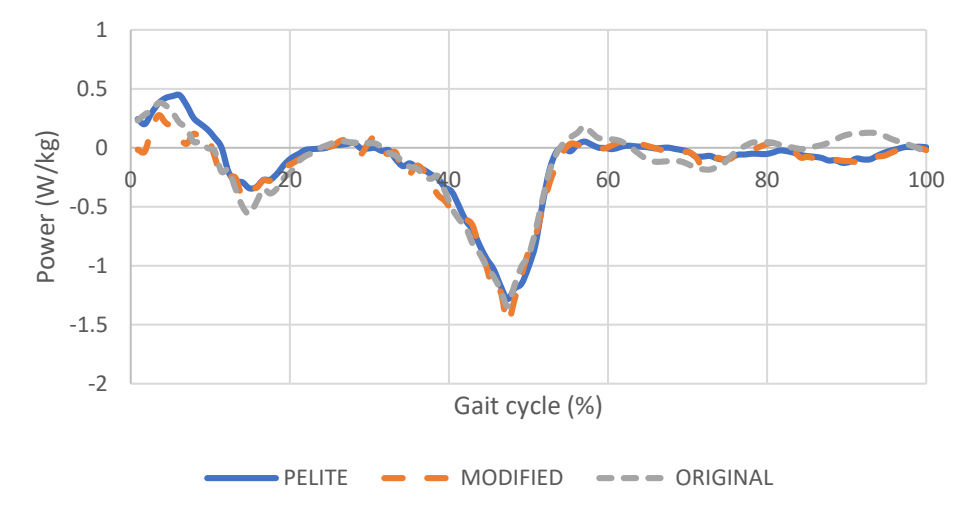

G)

Knee Angle (Non-Amputated)

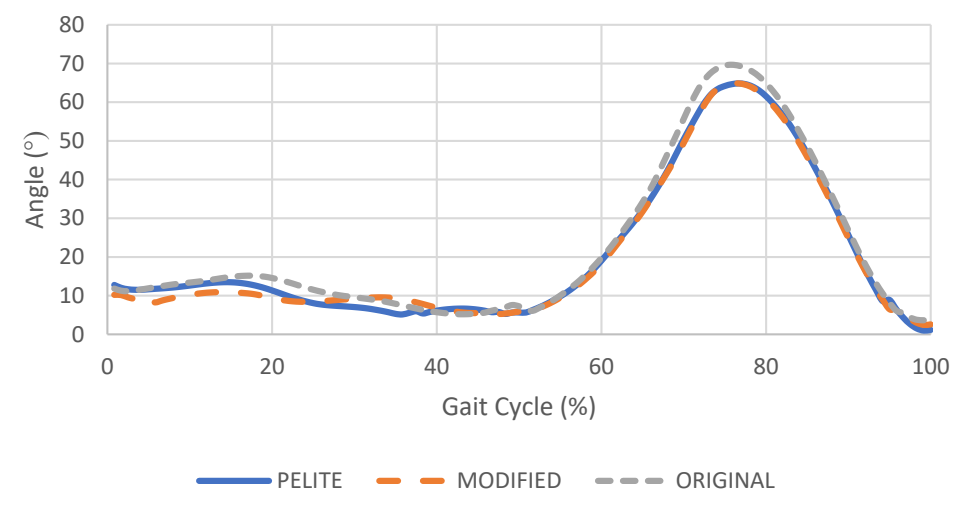

$\mathrm{H})$ Knee Power (Non-Amputated)

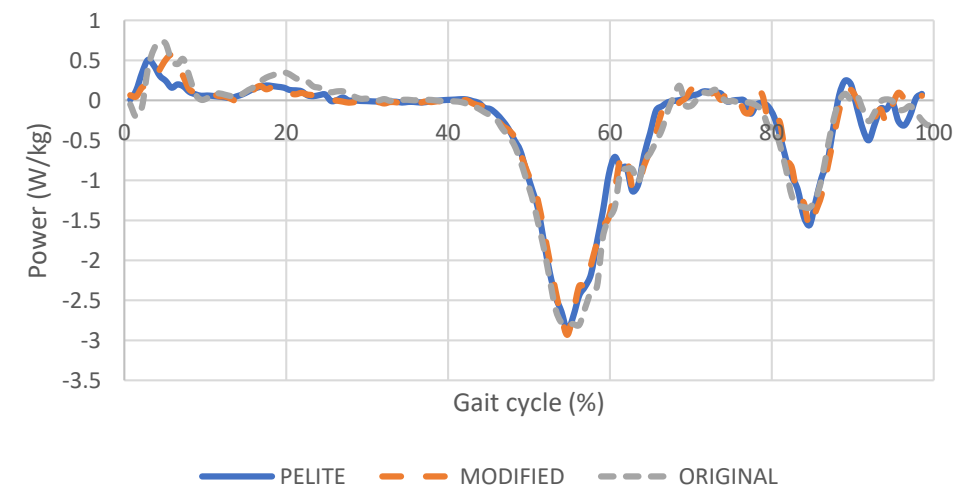

FIGURE 6. Gait analysis graphs for (A) ground reaction force (amputated); (b) ground reaction force (non-amputated); (c) ankle angle (non-amputated); (d) ankle angle (non-amputated); (e) knee angle (amputated); (f) knee power (amputated); (g) knee angle (non-amputated); and (h) knee power (non-amputated). The blue line is Pelite liner; the orange big dashed line is modified liner; and grey small dashed line is the subject's original liner 


\section{CONCLUSION}

A new prosthetic liner using polyurethane foam was successfully designed and constructed in the form of EVA-polyurethane-EVA sandwich. It was placed at the anterior-distal part of the residual limb as a replacement for the Pelite. Based on the biomechanical gait analysis, the subject walked better using the new modified liner followed by the Pelite liner and walked worst in his original liner. The study proved that the modified liner using polyurethane foam compensate the pain sensation experienced by the user at the residual limb as well as improved the walking gait of the prosthesis user.

\section{ACKNOWLEDGEMENTS}

The author(s) disclosed receipt of the following financial support for the research, authorship, and/or publication of this article: This work was supported by Universiti Malaya (IIRG004B-19SAH).

\section{REFERENCES}

Ali, S., Abu Osman, N.A. Razak, A. Hussain, S. \& Abas. W. The effect of dermo and seal-in $\times 5$ prosthetic liners on pressure distributions and reported satisfaction during ramp ambulation in persons with transtibial limb loss. Eur. J. Phys. Rehabil. Med. 51: 31-37.

Anderson, B.D., Nordquist, P., Skarman, E., Boies, M.T., Anderson, G.B. \& Carmack, D.B. 2007. Integrated lower extremity trauma simulator. In MMVR. pp. 19-24.

Andrysek, J. \& Eshraghi, A. 2016. Influence of prosthetic socket design and fitting on gait. In Handbook of Human Motion, edited by Müller B. \& Wolf, S. Springer International Publishing. pp. 1-25. https://doi.org/10.1007/978-3-31930808-1 76-1.

Arezoo Eshraghi, Noor Azuan Abu Osman, Hossien Gholizadeh, Sadeeq Ali \& Wan Abu Bakar Wan Abas. 2015. Interface stress in socket/residual limb with transtibial prosthetic suspension systems during locomotion on slopes and stairs. American Journal of Physical Medicine \& Rehabilitation 94(1): 1-10.

Biddiss, E. \& Andrysek, J. 2011. Upper and Lower Extremity Prosthetics for Children and Youth. Boca Raton: CRC Press.

Dudek, N.L., Marks, M.B., Marshall, S.C. \& Chardon, J.P. 2005. Dermatologic conditions associated with use of a lowerextremity prosthesis. Archives of Physical Medicine and Rehabilitation 86(4): 659-663.

Esposito, E.R., Stinner, D.J., Fergason, J.R. \& Wilken, J.M. 2017. Gait biomechanics following lower extremity trauma: Amputation vs. reconstruction. Gait \& Posture 54: 167-173.
Grimmer, M., Holgate, M., Ward, J., Boehler, A. \& Seyfarth, A. 2017. Feasibility study of transtibial amputee walking using a powered prosthetic foot. 2017 International Conference on Rehabilitation Robotics (ICORR). pp. 11181123.

Hossein Gholizadeh, Noor Azuan Abu Osman, Arezoo Eshraghi, Sadeeq Ali, Wan Abu Bakar Wan Abas \& Gholam Hossein Pirouzi. 2012. Transtibial prosthetic suspension: Less pistoning versus easy donning and doffing. Journal of Rehabilitation Research and Development 49(9): 13211330 .

Kamiar Ghoseiri, Mohammad Yusuf Rastkhadiv \& Mostafa Allami. 2018. Evaluation of localized pain in the transtibial residual limb. Canadian Prosthetics \& Orthotics Journal 1(2).

Kirkup, J.R. 2007. A History of Limb Amputation. Springer Science \& Business Media.

Klaassen, M., De Vries, E.G. \& Masen, M.A. 2019. Friction in the contact between skin and a soft counter material: Effects of hardness and surface finish. Journal of the Mechanical Behavior of Biomedical Materials 92: 137-143.

Lee, W.C., Zhang, M. \& Mak, A.F. 2005. Regional differences in pain threshold and tolerance of the transtibial residual limb: Including the effects of age and interface material. Archives of Physical Medicine and Rehabilitation 86(4): 641-649.

Li, W., Liu, X.D., Cai, Z.B., Zheng, J. \& Zhou, Z.R. 2011. Effect of prosthetic socks on the frictional properties of residual limb skin. Wear 271(11-12): 2804-2811.

McMonagle, C, Williams, A. \& Brentnall, L. 2007. SLSPO Transtibial Prosthetics Course Manual. Sri-Lanka School of Prosthetics and Orthotics.

Miller, M.S., Newgent, E.W., O'Connell, S.M. \& Broadus, C. 2017. A comprehensive scoring system to evaluate patient-centred risk factors regarding lower extremity amputation. Journal of Wound Care 26(Sup10): S20-S28.

Nazri Mohd Yusof, Jamalludin Ab Rahman, Ahmad Hafiz Zulkifly, Aminudin Che-Ahmad, Kamarul Ariffin Khalid, Ahmad Fadzli Sulong \& Naveen Vijayasingham. 2015. Predictors of major lower limb amputation among type II diabetic patients admitted for diabetic foot problems. Singapore Medical Journal 56(11): 626-631.

Plitz, W., Kuhn, V., Maier, A., Carl, C. \& Hagena, F. 1993. Injury mechanisms of the ankle joint in high ski boots: Photoelastic and mechanical investigations on the human bone specimen. In Skiing Trauma and Safety: Ninth International Symposium, edited by Johnson, R., Mote, C. $\&$ Zelcer, J. West Conshohocken, PA: ASTM International. pp. 150-161.

Porter, S. 2013. Tidy's Physiotherapy E-Book. Elsevier Health Sciences. 
Sadeeq Ali. 2015. Interface pressure between socket and residual limb in prosthesis with seal-in X5 and dermo liner during level ground, stairs, and ramp walking/Sadeeq Ali. PhD diss., University of Malaya (Unpublished).

Sankaran, Sakthivel, Pallikonda Rajasekaran Murugan, Jennifer Christy Johnson, Hazzana Jasmin Sheik Abdullah, Christal Marshalla Nirmal Raj, \& Deepika Ashokan. 2019. Prevention of skin problems in patients using prosthetic limb: A review of current technologies and limitations. 2019 International Conference on Communication and Signal Processing (ICCSP). pp. 0077-0081.

Smith, D.G. 2004. Prosthetic suspensions and components. In Atlas of Amputations and Limb Deficiencies: Surgical, Prosthetic, and Rehabilitation, edited by Douglas, J.W. \& Smith, G. Rosemont: American Academy of Orthopaedic Surgeons. p. 409.
Staros, A. \& Schwartz, R.S. 1988. Custom footwear: The role of computer-aided engineering. Journal of Testing and Evaluation 16(4): 417-420.

Van Valkenburg, S., Werner, F., Bhimji, S., White, B. \& Asseman, F. 2016. Assessment of physiological load testing of total knee implants. Journal of Testing and Evaluation 44(1): 258-267.

Department of Biomedical Engineering

Faculty of Engineering

University of Malaya

50603 Kuala Lumpur, Federal Territory

Malaysia

*Corresponding author; email: nasrul.anuar@um.edu.my

Received: 24 August 2020

Accepted: 26 January 2021 